\title{
NUTRIENTS INTAKE AND NUTRITIONAL STATUS OF STREET CHILDREN IN BANDUNG
}

\author{
Rita Patriasih ${ }^{1 *}$, Isma Widiaty ${ }^{1}$, Mira Dewi ${ }^{2}$ and Dadang Sukandar ${ }^{2}$ \\ ${ }^{1}$ Department of Home Economics Education, Faculty of Technology and Vocacional Education, \\ Indonesia Education University, Bandung, Indonesia \\ 2 Department of Community Nutrition, Bogor Agricultural University, Bogor 16680, Indonesia \\ * Corresponding Author : Departement of Home Economics Education, Faculty of Technology and \\ Vocacional Education, Indonesia Education University Bandung-West Java, Indonesia. Phone : 62- \\ 22-2013163 ex 3408; Facs: 62-22- 2011576; Email:harpabiru@yahoo.com
}

\begin{abstract}
The objectives of this research were to analyze food habits and nutrients intake, and health and nutritional status of street children. The research was carried out in the City of Bandung, West Java; Indonesia. A sample of 324 street children was selected randomly. The sample consisted of 232 boys and 92 girls. The data obtained from questionnaires. Means, standard deviation, frequency and proportion were calculated with a combination of software applications: Microsoft Excel and Statistical Analysis System. The result showed the level of consumption adequacy did not meet the recommended dietary allowances i.e. with the shortage of $10-15 \%$, this is an indication that the street children should be aware of their daily food consumption. The most common diseases suffered by the respondents were acute respiratory infections (ARI) (47\%). In addition, $22.7 \%$ and $18.4 \%$ of them suffered from diarrhoea and skin diseases, respectively. Blood haemoglobin status of street children shows that the incidence of anemia was 29.3\%. Based on the classification of nutritional status, $42.7 \%$ and $80.4 \%$ of street children were underweight and stunted, respectively.
\end{abstract}

Key words: nutrients intake, nutritional status, street children

\section{INTRODUCTION}

Children should be at home, school, or in a playing atmosphere in which there is a conducive interaction for the physical, motoric, social, psychological, and moral developments of children. However, such condition is not experienced by street children. The Social Department (1999) defined street children as children who spend most of their time to work for a living or wander around the streets or public places; whereas UNICEF gives the following definition: Street children are those who have abandoned their homes, school and immediate communities before they are sixteen years of age, and have drifted into a nomadic street life.

The number of such children population cannot yet be determined accurately because of the calculating difficulty - they are always mobile and the population continues to increase particularly at certain times. It is estimated that the number of world's street children has reached 30 - 170 million children (UNICEF, 2005 in Huang et al., 2005). Every year, the number of street children increases. UNICEF (2007) estimates the number of street children in 2020 can reach 800 millions if there is no serious effort to overcome the problems of street children.

Based on the data of 2006 from the Social Department, the Republic of Indonesia, the number of street children in Indonesia reached 144,889 . According to the survey by the Social Department in 2003, there were 15,028 street children in West Java. Most live in the City of Bandung (5,978 children) and Bekasi (1,800 children) (Sudaryat, 2004).

Nutrition, which they should have got as the priority to support development and growth, is often not present. Eating for fullness is merely their own major need; eating healthy and balanced food is not their main concern. So far there has been no accurate data about the nutritional status of street children.

Irregular eating habits and food quality below the standard of nutritional requirement have made street children susceptible to health problems. Nutritional deficiency is one of the causes of infectious diseases to an individual because the body's natural system of immunity has weakened. This condition is worsened by the exposure to heavy-metal polluted air they breathe in everyday, making them easily develop various infectious diseases 
which are closely related to the decreased level of immunity against germ infliction. A research in Guatemala found $92 \%$ of street children to be infected with bugs and moulds and $88 \%$ get respiratory infection. This is also the case with skin infection.

The objectives of this research were to analyze nutrients intake and nutritional status of street children in Bandung.

\section{METHOD}

\section{Research Design, Time, and Location}

This research was in the form of a survey. The research was carried out in the City of Bandung, West Java. The respondents (street children) were visited for the data collection through observation, interviews and measurements. The research lasted 12 months.

\section{Sampling}

The population in this research refers to a group of children doing activities on the streets. Their ages were below 18 years. A sample of 324 street children was selected randomly. The sample consisted of 232 boys and 92 girls. The sample represented the west, east, north and central parts of Bandung.

\section{Data Collection}

The primary data included food consumption, nutritional aspects involving anthropometric data of street children and blood hemoglobin level, and health status (acute respiratory infection, diarrhoea, skin infection).

\section{Data Processing and Analysis}

The data obtained from questionnaires and already edited on field was entered into the computerized file by using the software of Microsoft excels. Categorization and tabulation were made for the health status of children. The nutritional status of street children was measured by calculating the Z-scores of weight for age, height for age, and weight for height. The resulted mean, standard deviation, frequency and proportion were presented in the forms of tables. Means, standard deviation, frequency and proportion as well as tabulation were calculated with a combination of software applications: Microsoft Excel and Statistical Analysis System.

\section{RESULTS}

\section{Food Consumption}

The frequency of food consumption reflects one's consumption habits. In this study, the frequency of food consumption was presented based on the food types such as cereals/tubers, animal food, nuts, vegetables, and fruits.

Table 1 shows the statistic of street children according to the frequency of consumption of cereals/tubers. The types of cereals consumed relatively often included rice, corn, and noodles, while the tubers consumed included cassava and sweet potatoes. As can be seen from the table, it seems difficult to subsitute rice as the staple food with other foods. The consumption frequency of 69.2 times per month indicates that street children ate rice more than 2 times a day. While the consumption of other carbohydrate food sources was only about five times a month, except for the noodles, which reached 13.3 times per month.

Table 2 shows the frequency of consumption of animal food. For low-income community groups, consumption of animal food was a luxury. This research revealed that lamb consumption was only 0.2 times per month indicating that street children ate meat only about 2 times a year. The foods, which were relatively frequently consumed by street children included fish and eggs. As shown in the table, salty fish was consumed 12.1 times a month (2-3 days). Salty fish in Indonesia is cheap, and its salty flavor causes it unnecessary to be consumed in a large amount with rice. The street children also ate eggs with a frequency of 7.2 times per month since eggs are cheap and easily obtained. In addition, people have increasingly realized that eggs are nutritious foods that are good for health.

Table 1. Statistic of the Street Children based on Their Consumption Frequency of Cereals/Tubers (times/month)

\begin{tabular}{lcccccc}
\hline \multirow{2}{*}{ Foods } & \multicolumn{2}{c}{ Male } & \multicolumn{2}{c}{ Female } & \multicolumn{2}{c}{ Total } \\
\cline { 2 - 7 } & Mean & Std & Mean & Std & Mean & std \\
\hline Rice & 70.2 & 22.7 & 66.7 & 20.2 & 69.2 & 22.1 \\
Corn & 5.1 & 12.9 & 5.9 & 6.7 & 5.3 & 11.6 \\
Cassava & 3.9 & 5.7 & 4.8 & 11.0 & 4.2 & 7.5 \\
Sweet potatoes & 5.3 & 10.0 & 3.8 & 5.1 & 4.9 & 8.9 \\
Noodles & 13.9 & 23.3 & 11.4 & 13.6 & 13.3 & 21.2 \\
\hline
\end{tabular}


Table 2. Statistic of the Street Children based on Their Consumption Frequency of Animal Foods (times/month)

\begin{tabular}{lcccccc}
\hline \multirow{2}{*}{ Foods } & \multicolumn{2}{c}{ Male } & \multicolumn{2}{c}{ Female } & \multicolumn{2}{c}{ Total } \\
\cline { 2 - 7 } & Mean & std & Mean & std & Mean & std \\
\hline Lamb & 0.1 & 0.7 & 0.2 & 1.1 & 0.2 & 0.8 \\
Marine fish & 1.6 & 4.3 & 1.4 & 3.1 & 1.6 & 4.0 \\
Marinated fish & 6.4 & 16.3 & 6.0 & 8.7 & 6.3 & 14.6 \\
Fresh water fish & 4.1 & 8.2 & 2.4 & 3.9 & 3.6 & 7.3 \\
Impun Fish & 7.7 & 12.2 & 10.4 & 18.9 & 8.4 & 14.3 \\
Salty fish & 12.7 & 13.8 & 10.6 & 8.3 & 12.1 & 12.6 \\
Eggs & 7.0 & 13.9 & 7.8 & 18.5 & 7.2 & 15.3 \\
Milk & 0.4 & 2.5 & 2.5 & 22.9 & 1.0 & 12.0 \\
\hline
\end{tabular}

Processed legume foods commonly consumed by street children included tofu and soybean cake, each with a frequency of 16.3 times and 13.7 times per month. Tofu and soybean cake have become traditional foods for a long time because they are cheap and easily available in the markets. In terms of nutrition (because they are made of soybeans), tofu and soybean cake are known to have high nutritional quality. The other types of nuts quite frequently consumed included peanuts (6.4 times per month), green beans (4.3 times) and red beans ( 4.5 times). Beans of these types are generally processed as a kind of mixture in the cooking of vegetables in the household. Oncom as peanut products is generally consumed by the people living in Bandung West Java. However, in this study, the street children in Bandung (West Java) rarely consumed this food (1.3 times per month) (Table 3).

Table 3. Statistic of the Street Children based on their Consumption Frequency of Nuts (times/month)

\begin{tabular}{lcccccc}
\hline \multirow{2}{*}{ Foods } & \multicolumn{2}{c}{ Male } & \multicolumn{2}{c}{ Female } & \multicolumn{2}{c}{ Total } \\
\cline { 2 - 7 } & Mean & std & Mean & Std & Mean & std \\
\hline Tofu & 15.7 & 17.9 & 17.7 & 18.2 & 16.3 & 18.0 \\
Soybean cake & 13.3 & 14.3 & 15.0 & 13.6 & 13.7 & 14.1 \\
Oncom & 1.3 & 5.3 & 1.3 & 4.2 & 1.3 & 5.0 \\
Peanuts & 7.2 & 15.1 & 4.3 & 6.6 & 6.4 & 13.4 \\
Green beans & 4.1 & 9.0 & 4.9 & 7.3 & 4.3 & 8.6 \\
Red beans & 4.4 & 9.7 & 4.9 & 6.4 & 4.5 & 9.0 \\
Jengkol & 2.8 & 8.0 & 1.0 & 4.0 & 2.3 & 7.2 \\
Petai & 1.4 & 4.5 & 0.3 & 1.3 & 1.1 & 3.9 \\
\hline
\end{tabular}

For vegetable consumption, as shown in Table 4, the street children often consumed watercress (9.4 times per month), spinach (7.0 times), and carrot (6.3 times). In addition, consumption of cabbage and beans were also relatively high (about five times per month). In the case of vegetables, it can be said that the street children consumed a variety of vege- tables, and this is a reflection that food consumption diversification has been applied.

Table 4. Statistic of the Street Children based on Their Consumption Frequency of Leafy Vegetables (times/month)

\begin{tabular}{lcccccc}
\hline \multirow{2}{*}{ Foods } & \multicolumn{2}{c}{ Male } & \multicolumn{2}{c}{ Female } & \multicolumn{2}{c}{ Total } \\
\cline { 2 - 7 } & Mean & std & Mean & std & Mean & std \\
\hline Spinach & 6.8 & 13.3 & 7.4 & 7.4 & 7.0 & 12.0 \\
Watercress & 9.5 & 15.1 & 9.3 & 11.2 & 9.4 & 14.1 \\
Mustard & 3.9 & 7.7 & 3.8 & 6.3 & 3.9 & 529 \\
Carrot & 5.7 & 9.5 & 8.1 & 8.4 & 6.3 & 9.2 \\
Cabbage & 5.7 & 9.1 & 5.3 & 7.2 & 5.6 & 8.6 \\
Cassava leaves & 3.4 & 6.0 & 2.6 & 5.2 & 3.2 & 5.8 \\
Papaya leaves & 0.6 & 2.2 & 1.9 & 5.9 & 1.0 & 3.6 \\
Melinjo leaves & 1.6 & 4.3 & 1.3 & 3.3 & 1.5 & 4.1 \\
Long beans & 5.2 & 9.3 & 4.7 & 6.1 & 5.0 & 8.6 \\
Lettuce & 1.4 & 4.9 & 0.7 & 2.5 & 1.2 & 4.4 \\
\hline
\end{tabular}

The most consumed vegetables included tomato (10.9 times per month), cucumber (7.1 times), and squash (4.5 times). Tomatoes are fruit vegetables that can be made into chili sauce, salads, or a mixture of vegetables in the household. The simplicity of their processsing makes tomatoes become the most frequently consumed vegetables (Table 5).

Fruit consumption (see Table 6) shows that street children often ate rambutans $(12.2$ times per month) because the survey was being conducted during the rambutan season. They also often ate guavas (10.6 times per month) and bananas (8.5 times per month). Other fruits were also consumed but less frequent.

Table 5. Statistic of the Street Children based on Their Consumption Frequency of Fruit Vegetables (times/month)

\begin{tabular}{lcccccc}
\hline \multirow{2}{*}{ Foods } & \multicolumn{2}{c}{ Male } & \multicolumn{2}{c}{ Female } & \multicolumn{2}{c}{ Total } \\
\cline { 2 - 7 } & Mean & Std & Mean & std & Mean & std \\
\hline Squash & 4.3 & 6.3 & 4.8 & 5.8 & 4.5 & 6.2 \\
Tomato & 11.7 & 22.5 & 8.5 & 9.4 & 10.9 & 19.9 \\
Cucumber & 8.1 & 14.1 & 4.5 & 5.8 & 7.1 & 12.5 \\
Baby jackfruit & 3.6 & 11.7 & 2.8 & 5.1 & 3.4 & 10.4 \\
Eggplant & 2.3 & 5.6 & 2.5 & 8.3 & 2.4 & 6.4 \\
Melinjo & 2.3 & 8.7 & 2.4 & 5.7 & 2.3 & 8.0 \\
\hline
\end{tabular}

Based on Table 7, it can be seen that fried foods quite frequently consumed included fried tofus (consumed 16.2 times per month), bakwan (14.2 times), fried soybean cakes (14.0 times), and fried bananas (11.4 times). Access to fried foods in the street is easy because there are vendors everywhere, besides, they also very cheap and rather filling. Hence, fried foods became a favorite for the street children and were consumed more 
often. Other snack foods which were also quite frequently consumed included meatballs and chicken noodles. Both types of snacks are often consumed as a substitute food for lunch/ dinner and generally favored by many people (including street children). The sellers of meatballs/chicken noodles go around everywhere; therefore, they are easily accessible by the public.

Table 6. Statistic of the Street Children based on Their Consumption Frequency of Fruits (times/month)

\begin{tabular}{lcccccc}
\hline \multirow{2}{*}{ Foods } & \multicolumn{2}{c}{ Male } & \multicolumn{2}{c}{ Female } & \multicolumn{2}{c}{ Total } \\
\cline { 2 - 7 } & Mean & Std & Mean & std & Mean & std \\
\hline Guava & 10.8 & 13.9 & 9.8 & 18.4 & 10.6 & 15.2 \\
Papaya & 3.7 & 6.0 & 4.9 & 7.1 & 4.0 & 6.3 \\
Mango & 3.8 & 6.9 & 4.6 & 5.6 & 4.0 & 6.5 \\
Pineapple & 3.0 & 16.5 & 1.1 & 3.8 & 2.5 & 14.3 \\
Banana & 8.4 & 11.1 & 9.0 & 15.6 & 8.5 & 12.4 \\
Ripen Jackfuit & 2.3 & 5.9 & 1.8 & 4.5 & 2.2 & 5.5 \\
Rambutans & 11.7 & 14.6 & 13.4 & 18.8 & 12.2 & 15.8 \\
Orange & 4.4 & 7.3 & 6.8 & 7.8 & 5.0 & 7.5 \\
Salacca & 3.0 & 6.3 & 2.7 & 4.8 & 2.9 & 5.9 \\
Durians & 0.5 & 2.4 & 0.7 & 3.5 & 0.6 & 2.7 \\
Apple & 0.1 & 0.8 & 0.7 & 2.5 & 0.2 & 1.5 \\
Dukuh & 0.3 & 1.7 & 0.0 & 0.1 & 0.2 & 1.5 \\
Mangosteen & 0.1 & 1.7 & 0.0 & 0.0 & 0.1 & 529 \\
Melon & 0.1 & 2.0 & 0.0 & 0.0 & 0.1 & 1.7 \\
Watermelon & 0.1 & 0.9 & 0.4 & 2.1 & 0.2 & 1.3 \\
Soursop & 0.2 & 2.0 & 0.0 & 0.0 & 0.1 & 1.7 \\
\hline
\end{tabular}

Table 7. Statistic of the Street Children based on Their Consumption Frequency of Snacks (times/month)

\begin{tabular}{lcccccc}
\hline \multirow{2}{*}{ Foods } & \multicolumn{2}{c}{ Male } & \multicolumn{2}{c}{ Female } & \multicolumn{2}{c}{ Total } \\
\cline { 2 - 7 } & Mean & Std & Mean & std & Mean & std \\
\hline Meatballs & 10.6 & 12.8 & 11.5 & 13.1 & 10.9 & 12.9 \\
Siomay & 58.0 & 103.4 & 73.8 & 115.6 & 62.2 & 106.9 \\
Fried Rice & 11.5 & 17.5 & 11.2 & 12.9 & 11.4 & 16.4 \\
Chicken Noodles & 4.8 & 8.2 & 3.1 & 4.4 & 4.4 & 7.4 \\
Bakwan & 14.9 & 18.2 & 12.2 & 13.6 & 14.2 & 17.1 \\
Fried Tofu & 16.2 & 18.7 & 16.0 & 15.0 & 16.2 & 17.7 \\
Fried soybean cake & 14.2 & 17.3 & 13.5 & 12.6 & 14.0 & 16.2 \\
Batagor & 0.8 & 3.8 & 0.9 & 3.5 & 0.8 & 3.7 \\
Porridge & 0.0 & 0.6 & 1.1 & 9.8 & 0.3 & 5.1 \\
Pop Ice & 0.0 & 0.3 & 0.0 & 0.0 & 0.0 & 0.2 \\
Bread & 0.3 & 4.0 & 0.0 & 0.0 & 0.2 & 3.4 \\
Seblak & 0.0 & 0.0 & 0.3 & 2.3 & 0.1 & 1.2 \\
\hline
\end{tabular}

For other food consumption, (see Table $8)$, sugar, tea and coffee were frequently consumed by the street children i.e. 15.2 times, 16.3 times and 8.4 times per month respectively. Drinking tea and coffee has become a habit for the Indonesian people (including the street children). After dinner, most Sundanese people drink tea, while coffee is consumed in the morning or evening. In addition, other foods that were consumed included crackers (13.3 times per month), ketchup (9.7 times) and sauces (9.4 times). These three types of food are commonly consumed as side dish or flavor when eating rice.

Table 8. Statistic of the Street Children based on Their Consumption Frequency of Other Types of Foods (times/month)

\begin{tabular}{lccccccc}
\hline \multirow{2}{*}{ Foods } & \multicolumn{2}{c}{ Male } & \multicolumn{2}{c}{ Female } & \multicolumn{2}{c}{ Total } \\
\cline { 2 - 7 } & Mean & Std & Mean & std & Mean & Std \\
\hline Sugar & 16.7 & 24.0 & 11.1 & 13.9 & 15.2 & 21.8 \\
Tea & 18.0 & 24.3 & 11.5 & 14.7 & 16.3 & 22.3 \\
Coffee & 10.4 & 18.8 & 2.7 & 7.1 & 8.4 & 16.8 \\
Sauce & 9.4 & 13.6 & 9.6 & 13.1 & 9.4 & 13.4 \\
Crackers & 13.7 & 11.8 & 12.2 & 12.2 & 13.3 & 11.9 \\
Ketchup & 10.1 & 15.2 & 8.6 & 9.5 & 9.7 & 13.9 \\
\hline
\end{tabular}

The consumption of food that had been converted into energy and nutrients can be seen in Table 9. The average of energy adequacy level was $83.0 \%$, the level of nutrition intake (protein, vitamins and minerals) exceeded $80.0 \%$ of RDA, and the iron already reached $111.1 \%$. The figures as shown in the table can be said to be better compared with the results of surveys about the adequacy of nutrition of children under five or households in rural areas. Living in the streets enables the street children to access food more easily because food vendors are everywhere. Besides, the street children get money more easily from their activities in the streets, and some of the money earned is spent to buy foods in the streets.

Table 9. Statistic of the Street Children based on Consumption, RDA and \% RDA

\begin{tabular}{lcccccc}
\hline \multirow{2}{*}{ Nutrients } & \multicolumn{2}{c}{ Consumption } & \multicolumn{2}{c}{ RDA } & \multicolumn{2}{c}{ \%RDA } \\
\cline { 2 - 7 } & Mean & Std & Mean & std & Mean & Std \\
\hline Energy (kcal) & 1807 & 502 & 2215 & 252 & 83.0 & 22 \\
Protein (g) & 45.9 & 15.1 & 56.6 & 10.4 & 84.7 & 23.8 \\
Calsium (mg) & 571 & 169 & 643 & 68 & 93 & 27 \\
Phosphor (mg) & 415 & 120 & 478 & 35 & 88 & 26 \\
Iron (mg) & 13.4 & 5.2 & 17.7 & 4.6 & 111.1 & 43.9 \\
Vitamin A (RE) & 509 & 193 & 570 & 101 & 91 & 28 \\
Vitamin B (mg) & 1.0 & 0.3 & 1.0 & 0.0 & 97.0 & 27.0 \\
Vitamin C (mg) & 50.0 & 16.0 & 55.7 & 5.7 & 90.6 & 27.8 \\
\hline
\end{tabular}

The diversity of the consumption presented at the previous tables of the frequency of food consumption shows that the consumption profile of the street children was relatively good. However, the level of consumption adequacy did not meet the recommended dietary allowances i.e. with the shortage of 10$15 \%$. This is an indication that the street children should be aware of their daily food consumption. The shortage as much as $10-15 \%$ of 
their daily energy and nutrients can affect their nutritional status in the future. If the level of nutrition adequacy is classified according to the percentage of RDA (see Table 10), it can be seen that $50 \%$ or more of street children did not meet the expected nutrition adequacy. Only one-fifth of the street children could meet the energy consumption and nutrition with a range of $90-110 \%$ of RDA.

Table 10. Distribution of Street Children based on Their Level of Nutrition Adequacy

\begin{tabular}{lccccc}
\hline \multirow{2}{*}{ Nutrients } & \multicolumn{5}{c}{ Classification of \% of RDA } \\
\cline { 2 - 6 } & $<\mathbf{7 0}$ & $\mathbf{7 0 - 8 9}$ & $\mathbf{9 0 - 1 1 0}$ & $\mathbf{1 1 1 - 1 3 0}$ & $>\mathbf{1 3 0}$ \\
\hline Energy (kcal) & 36.8 & 30.3 & 18.7 & 9.0 & 5.2 \\
Protein (gr) & 34.3 & 29.9 & 18.7 & 9.7 & 7.5 \\
Calsium (mg) & 27.8 & 16.7 & 27.8 & 16.7 & 11.1 \\
Phosphor (mg) & 27.2 & 35.1 & 18.4 & 10.5 & 8.8 \\
Iron (mg) & 11.1 & 44.4 & 11.1 & 0.0 & 33.3 \\
Vitamin A (RE) & 28.9 & 28.9 & 18.4 & 7.9 & 15.8 \\
Thiamin (mg) & 21.1 & 20.0 & 27.4 & 18.9 & 12.6 \\
Riboflavin (mg) & 25.3 & 31.6 & 27.4 & 12.6 & 3.2 \\
Vitamin C (mg) & 32.0 & 20.0 & 24.0 & 12.0 & 12.0 \\
\hline
\end{tabular}

Some street children (15-20\%) even consumed energy and nutrients more than $110 \%$ of RDA. If the energy and nutrients intake exceeds the daily nutrition rates, this excess will eventually lead to weight problems (overweight and obesity). It is then very essential that the street children also get access to relevant information on health nutrition so they can maintain their health better.

\section{Health Status}

A person's health status is related to the circumstances of his or her illness and is the result of the process of interaction between host factors, diseases and environmental agents. A disease itself is influenced by environmental factors, nutrition and immunity con ditions and access to health services.

Table 11 shows that the most common disease suffered by respondents was acute respiratory infections (ARI) i.e. 47\%. In addition, the street children $(22.7 \%$ and $18.4 \%)$ also frequently suffered diarrhoea and skin diseases. Street children spent more time on the street than other children, and streets are sources of diseases because of air pollution by motor vehicle fumes, and pathogens from the public street users coming from spark sneeze, cough or spit.

Because of their relatively high exposure to the street, it is very important for street children to maintain their personal hygiene and good immunity status. ARI is usually spread through hand or air containing droplets that contain bacteria, whereas diarrhoea is spread usually through contaminated foods or hands. When viewed from the habit of washing hands by the street children which was still low, it is not surprising that the second event of this disease was also high.

Table 11. Percentage of Street Children based on Their Health Status

\begin{tabular}{lcccccc}
\hline \multirow{2}{*}{\multicolumn{1}{c}{ Notes }} & \multicolumn{2}{c}{ Male } & \multicolumn{2}{c}{ Female } & \multicolumn{2}{c}{ Total } \\
\cline { 2 - 7 } & Yes & No & Yes & No & Yes & No \\
\hline $\begin{array}{l}\text { Child acute respiratory } \\
\text { infections (ARI) }\end{array}$ & 46.0 & 54.0 & 50.0 & 50.0 & 47.0 & 53.0 \\
Diarrhoea & 25.1 & 74.9 & 16.3 & 83.7 & 22.7 & 77.3 \\
Skin Disease & 20.9 & 79.1 & 11.6 & 88.4 & 18.4 & 81.6 \\
\hline
\end{tabular}

In addition to the invasion of bacteria, child respiratory infection of the street children can also be exacerbated by the presence of metal contamination from toxic motor vehicle fumes. Skin infections often occur due to lack of personal hygiene habits such as bathing, changing clothes and wearing their own towels. For street children, the risk of skin diseases was higher by their presence in the streets; therefore, it needs special attention to protect street children from these diseases.

\section{Nutritional Status}

Nutritional status reflects how far someone's physiological needs for nutrients have been fulfilled. When the nutrients are consumed in sufficient quantities to meet the needs of the body and metabolism, it is said the the nutritional status to be optimal. This situation will support good growth and development, health care, and physical activity, and help prevent disease. Conversely, when nutrients are consumed in excessive or less amount, the body will adapt to achieve homeostatic state that maintains physiological functions. When excess or deficiency condition last long, it will result in interference with the functions of the body and the occurrence of diseases (Mahan \& Stump, 2007).

Assessment of nutritional status should ideally be done by taking into account the medical history, nutrition, social status, anthropometric measurements, and laboratory data analysis. In this study, nutritional status was measured by the anthropometric assessment of body weight, height, and levels of haemoglobin in the blood.

According to $\mathrm{WHO}$, the determination of the category of underweight (thin), healthy weight (normal), or overweight and obese (ex- 
cessive) at the age of $5-19$ is conducted by using the Z-score. If $z$ is $<-2$, the category is thin; If $z$ is $-2 \leq z \leq+2$, the category is normal, and if $z$ is $>+2$, the category is excessive (Tables 12 and 13).

Table 12. Statistic of the Street Children based on Their $\mathrm{Hb}$, Body Weight, and Height

\begin{tabular}{lcccccc}
\hline \multirow{2}{*}{ Nutritional Status } & \multicolumn{2}{c}{ Male } & \multicolumn{2}{c}{ Female } & \multicolumn{2}{c}{ Total } \\
\cline { 2 - 6 } & Mean & std & Mean & std & Mean & std \\
\hline $\begin{array}{l}\text { Haemoglobin level } \\
(\mathrm{mg} / \mathrm{dl})\end{array}$ & 13.2 & 1.7 & 11.9 & 1.4 & 12.9 & 1.7 \\
Weight $(\mathrm{kg})$ & 40.5 & 11.8 & 35.8 & 10.5 & 39.3 & 11.6 \\
Height $(\mathrm{cm})$ & 148.3 & 17.4 & 138.6 & 11.6 & 145.8 & 16.6 \\
\hline
\end{tabular}

From Table 13, it can be seen that the underweight and stunted conditions were experienced by $42.7 \%$ and $80.4 \%$ of street children, respectively. Some research revealed that street children are categorized as vulnerable groups who lack of nutritions. According to Effendi \& Uripi (1997), this may be due to (1) less food intake because the money for buying foods is used to buy cigarettes, glue, or liquor; (2) malabsorption which disrupts the body absorption level (health) so that diseases may appear. In this study, this was not visible, because even if they were not economically strong, it seems the need for food intake as energy sources has been adequately supplied to achieve ideal body weight. If seen from the level of adequacy of energy and other nutrients in which only a fifth of street children who could meet the energy consumption and nutrients with a range of RDA of $90-110 \%$, it is alleged that there is a tendency for a decline in nutritional status in the future. Therefore, a special attention must be given to this matter since the street children (the respondents) who are young and adolescents still require good nutrition for their growth. According to Notoatmodjo (1997), adolescence belongs to the vulnerable age of nutrition. Therefore, if food consumption is not balanced with the needs of calories for growth and other activities, there will be a deficiency, which can ultimately hamper growth. In fact, the young female respondents usually tended to keep up their appearances by reducing foot intake so they would not get fat.

The result of research on blood haemoglobin status of street children shows that the incidence of anemia was $29.3 \%$ (Table 14). Based on gender, the percentage of anemic young female street children was higher i.e. $45.3 \%$, while that of the male street children reached $23.4 \%$.
Table 13. Distribution of Street Children based on the Classification of Their Nutritional Status (Anthropometry)

\begin{tabular}{lccc}
\hline \multirow{2}{*}{ Variables } & \multicolumn{3}{c}{ Classification of Nutritional Status } \\
\cline { 2 - 4 } & Inadequate & Normal & Excessive \\
\hline WAZ & 42.7 & 56.7 & 0.6 \\
HAZ & 80.4 & 19.6 & 0.0 \\
WHZ & 2.8 & 94.4 & 2.8 \\
\hline
\end{tabular}

Table 14. Distribution of Street Children based on Their Haemoglobin Status

\begin{tabular}{lcccccc}
\hline \multirow{2}{*}{ Haemoglobin status } & \multicolumn{2}{c}{ Male } & \multicolumn{2}{c}{ Female } & \multicolumn{2}{c}{ Total } \\
\cline { 2 - 7 } & $\mathrm{n}$ & $\%$ & $\mathrm{n}$ & $\%$ & $\mathrm{n}$ & $\%$ \\
\hline Normal $(\geq 12 \mathrm{mg} / \mathrm{dl})$ & 180 & 76.6 & 47 & 54.7 & 227 & 70.7 \\
Anemia $(<12 \mathrm{mg} / \mathrm{dl})$ & 55 & 23.4 & 39 & 45.3 & 94 & 29.3 \\
\hline
\end{tabular}

Blood haemoglobin level represents the blood's ability to deliver oxygen to all parts of the body, which among others is determined by good nutrition. Anemia or the haemoglobin level which is less than $12 \mathrm{mg} / \mathrm{dl}$ is mostly caused by poor intake of both macro and micro nutrients. In women who have experienced menstruation, the risk of anemia is greater because of the bleeding process, so the need for nutrients for the formation of red blood cells is also greater. A woman who suffers from anemia will have a greater risk for experiencing difficulties in the process of pregnancy and childbirth, and her baby is also more prone to various disorders.

The female street children are the future mothers of the future; therefore, their needs of adequate nutrients to avoid anemia is also important. In this case, the understanding of anemia as a part of nutrition education for female street children should be noted.

\section{CONCLUSION}

The average of energy adequacy level was $83.0 \%$, the level of nutrition intake (protein, vitamins and minerals) exceeded $80.0 \%$ of RDA, and the iron already reached $111.1 \%$. The level of consumption adequacy did not meet the recommended dietary allowances i.e. with the shortage of $10-15 \%$. This is an indication that the street children should be aware of their daily food consumption. If the level of nutrition adequacy is classified according to the percentage of RDA, it can be seen that $50 \%$ or more of street children did not meet the expected nutrition adequacy. Only one-fifth of the street children could 
meet the energy consumption and nutrition with a range of $90-110 \%$ of RDA.

The most common diseases suffered by the respondents were child acute respiratory infections (ARI) (47\%). In addition, $22.7 \%$ and $18.4 \%$ of them suffered from diarrhoea and skin diseases respectively.

The haemoglobin level of the average street children was $12.9 \mathrm{mg} / \mathrm{dl}$. The boys had higher haemoglobin level of $13.2 \mathrm{mg} / \mathrm{dl}$ while the girls reached $11.9 \mathrm{mg} / \mathrm{dl}$, and this occured because the street children especially the female women generally teenagers and suffered from periods. Blood haemoglobin status of street children shows that the incidence of anemia was $29.3 \%$. Based on gender, the percentage of female respondents was higher i.e. $39 \%$, while that of the male street children was $23.4 \%$.

The average weight of the male street children was $40.5 \mathrm{~kg}$ and the height was 148.3 $\mathrm{cm}$. In contrast, the average weight for female ones was $35.8 \mathrm{~kg}$ and the height was $138.6 \mathrm{~cm}$. Based on the classification of nutritional status, $42.7 \%$ and $80.4 \%$ of street children were underweight and stunted respectively.

\section{ACKNOWLEDGMENTS}

The research team would like to extend its gratitude and appreciation to the following parties: Neys Van-Hoogstraten Foundation for funding this project; NGOs and social workers in Bandung for facilitating the research project; medical doctors who participated in data collection; Chairman of the Department of Home Economics Education, Indonesia Education University (UPI); Bandung Regency Officer in West Java who gave permits to collect data in the study areas; and the research assistant for doing administrative works as well as enumerators who helped to collect data from the field.

\section{REFERENCES}

Effendi YH \& V Uripi. 1997. Pengantar Epidimiologi Gizi. Jurusan Gizi Masyarakat dan Sumberdaya Keluarga, Fakultas Pertanian, Institut Pertanian Bogor, Bogor.

Hartini, Subekti \& Nur Ainy. 2001. The IQ and EQ Profile of Street Children. Jurnal Penelitian Dinamika Sosial, Fakultas Psikologi, Universitas Airlangga, 2(3), 32-40.

Huang CC, P Barreda, V Mendoza, L Guzman \& P Gilbert. 2005. A comparative analysis of abandoned street children and formerly abandoned street children in La Paz, Bolivia: "Street children: the facts". Journal of the American Academy of Child and Adolescent Psychiatry. www. findarticles.com [Januari 2008].

Mahan LK \& S Escott-Stump. 2007. Krause's Food, Nutrition, \& Diet Therapy. Elsevier.

Ministry of Social Affairs. 2006. Street Children Data. West Java Social Affairs Office, Bandung.

Notoatmodjo S. 1997. Pengantar Pendidikan Kesehatan dan Ilmu Perilaku Kesehatan. (Introduction to Health Education and Health Behavioral Sciences). Ando Offset, Yogyakarta.

Sudaryat A. 2004. Free from Street Children, a Bandung Program. www.pikiran-rakyat. com [ Juli 2008].

UNICEF. 2007. Street Children. http://www. unicef.org [Januari 2008].

[WHO] World Health Organization. 2007 Growth reference data for 5-19 years. wWw.who.int/growthref/en/[Mei 2008]. 